\title{
FRESH AND SALT: Introduction
}

\section{Transforming Cultures eJ ournal, \\ Vol. 1 No. 2, June 2006 \\ http:// epress.lib.uts.edu.au/journals/TfC}

\section{Heather Goodall \\ Trans/forming Cultures June 2006}

The Cadigal and Wangal Wangal people, traditional owners of the Sydney country on which we met for the Fresh and Salt symposium, were water people. The rivers and the ocean, the beaches and wetlands all around, were their country as much as the earth on which the city was built. We know this from the survivors of those communities who have continued to live in Sydney. We know too from the ways in which those traditional owners inscribed the places which related them to the waters. They engraved designs and figures onto the rocks of the headlands, they amassed huge middens with the bounty of generations of harvests and they relaxed together in water-fronted sandstone caves where they stencilled the marks of many hands on the walls to record their shared pleasure. Since the British invasion there have been many Aboriginal people who have come to Sydney after being displaced from their own homelands, and they have taken up the responsibilities of the local traditional owner where they had passed away under the colonial impact. Some came from along the coast, with the same experience of the confluence of fresh water flowing to the salt sea, but others came from the inland, whose experiences were with fresh, wide, meandering rivers with very different fish, birds and stories. For all of them, water was and remains central to their economy, social life and stories.

The Fresh and Salt symposium was about water, which is now an issue of urgent interest in Australia and the region. ${ }^{1}$ Relationships between people and water, and

\footnotetext{
${ }^{1}$ This symposium was convened by Trans/forming Cultures (TfC), the UTS Centre for Culture and Communications in the Faculty of Humanities and Social Science. It was generously supported by the Asia Pacific Futures Network and by the International Centre of Excellence in Asia Pacific Studies. The workshop was initiated and conducted by researchers from the centre, including Stephanie Donald [then TfC Director], Heather Goodall, Kate Barclay, James Goodman, Stephen Muecke and Devleena Ghosh [current TfC Director]. Participants were drawn from a number of active research networks associated with TfC, including the China Node of the APFN, the South Asia Network and the Research Initiative on International Activism.
} 
particularly those of Indigenous people, were the focus of its four themes: freshwater rivers, oceans, borders and commons. Participants at the symposium included activists and academic researchers who brought with them an extraordinarily broad disciplinary background. They ranged from cultural analysts to freshwater biologists, from historians and anthropologists to lawyers, political scientists and geographers. This generated vigorous and wide-ranging discussions, opening up unfamiliar comparisons between conditions on inland freshwater rivers and those of ocean island societies, or between the politics of modernising technologies on vast tropical rivers like the Mekong with those of arid zone rivers like those in inland China and Australia. In doing so, these discussions probed the ways in which the tools of social and cultural analysis can be usefully engaged with those of policy, biology and economics. This introductory essay argues that the papers refined and presented here reflect the qualities of the symposium discussions. They illuminate the ways in which people generate meanings for water, the ways the political battles over water are fought out and the ways in which water as rivers or oceans has formed fruitful but contested border zones across the region.

The first of these concerns the rich, complex but unstable meanings with which water is invested. My work on fresh water in Australia has suggested the historically-specific dimensions of this complexity which we can see in the everyday language used to talk about water. When they arrived in Australia, the invading British found that water baffled them: at once obvious and familiar, it always acted in a contrary way. Fresh water was of course a biological and agricultural need, and salt water was a long heritage for seafaring peoples were now in desperate need of regular ocean communication. But because the water in this southern colony did not behave at all in ways the settlers knew, they have left us a vocabulary for inland rivers and fresh waters which bears the marks of their confusion and surprise.

Like colonial race relations, western thinking about nature has tended to be posed around dichotomies, assumptions of separation and clear boundaries. The title of the symposium, Fresh and Salt, is an example of the expectation of clear boundaries between the two, although of course the European experience of estuaries already prepared the settlers for a liminal zone of intermixture and indeterminacy. In Australia the confusion between fresh and salt goes much further in space and time than estuaries. 
Here there are salt springs, many of which line river banks. Some rivers are in fact largely fed from underground water sources rather than from rain. ${ }^{2}$

So naturally occurring salt water flows into the largest of the inland rivers, the mighty Darling and the Murray, in a salting process which has for centuries been adjusted and regulated by the occasional high floods and constant 'freshes' which flow down the water ways. But with the rising impacts of western agriculture and most recently of industrialised irrigated farming, the salt springs have been compounded by the salt from a rising water table under the planted paddocks, leaving ugly white salt scalds and unusable sour ground where dead trees mark the way the salt flows into the main river, poisoning it as it goes. Salinity on land and increasingly saline 'fresh' inland rivers have become the marker of modernity in Australia’s once fertile wheat bowl.

Beyond the content of the water, it flowed in Australia in such bizarre and unexpected ways, and lay in shapes and channels so unfamiliar, that the English had to borrow local words even to speak about the waters they saw. Of all the topics for which the settlers felt they needed to learn indigenous vocabulary, that of water has led to more permanent incorporation into English that most others. So we now talk about billabongs, gilgais and warambools with barely a register that they reflect the settlers' incomprehension of the way water worked in Australia.

But in some places water doesn't seem to be there at all. Can a place be a river if it has no water? Yet the ancient riverbeds are key elements of life in central Australia, where water continues to flow beneath the ground but only occasionally above it. These are wide expanses of sand which mark the water's power when it is flowing. For the rest of the time these beds allow a fruitful camping place, mercifully free from thorns and snakes, a welcome for people to meet, share food, stories and ceremonies around the hearth and sleep safely till dawn in the cool sand.

Where the rivers do flow they are wildly variable and unpredictable and have been so for millennia. This has generated a complex dependent ecology of plant and animal life forms which are adapted to variability. The shifts to regular flows which have come from dams and irrigation pumps have choked off the freshes and floods which stimulate

\footnotetext{
${ }^{2}$ A.J. Boulton \& P.J. Hancock (2006) "Rivers as groundwater-dependent ecosystems: a review of degrees of dependency, riverine processes and management implications," Australian Journal of Botany 54.
} 
breeding cycles, starving the native species of the signals they need to regenerate and survive. And in flood, the rivers are not confined by any stable or reliable banks, but instead flow widely across the country, sometimes filling up channels which lie waiting, sometimes for decades, for the flows to come. Other times the waters flow in unpredictable ways, linking up distant watercourses, causing the water to flow in unexpected directions and with a whole rainbow of different colours as silt is carried down from separate floodplains to be mingled as it is dropped onto what will again be known as 'the black soil' once the flood has passed. Nor is the flood gone when the water appears to have flowed on. The black soil holds water deeply trapped within its clay structure, so it is fertile and sought after, despite its boggy qualities. And the waters that create it stay on in the imagination of the farmers when they talk about it, however dry it seems to be, as 'sweet ground', 'that flooded country'.

Yet despite drawing on local language to name water and its flows, the colonisers also left traces of their engagements in other colonies. The word 'tank' for example, so common now in rural Australia as a man-made dug-out depression to store water, sounds like English, but in fact derives from the Gujerati tankh [perhaps the Sanskrit tagada for 'pond'] and used to describe the extensively developed systems of water storages in India. ${ }^{3}$ Such borrowings reveal a shared English experience across the colonies of the Empire, and they have been taken by Australian researchers to signal the engineering and modernising role the British saw for themselves, particularly concerning water, in which the damming and channelling of rivers was a key aspect of what they considered 'the white man's burden'. But such words as tank arrived long before the British engineering profession developed. ${ }^{4}$ In fact what seems to have been occurring was that the English were only the agents of transfer, bringing to Australia the long established local Indian technologies for rainwater harvesting and distribution. 'Sinking a tank' is a whole profession in rural Australia, but is seldom recognised as the imported Indian knowledge it is. So the vocabulary of water reflects the deepest complexities of colonialism, not only the exercise of colonial power over people and nature, but the multi-directional learning and appropriation which has shaped the futures of both colonised and colonisers.

\footnotetext{
3 J.M. Powell (1991) Plains of Promise, Rivers of Destiny: Water Management and the Development of Queensland, 1824-1990, Queensland, Bowen Hills: Boolarong Publications; W.S. Ransom (ed) (1988) The Australian National Dictionary, Melbourne: Oxford University Press, p. 663.

${ }^{4}$ J.M. Powell (1976) Environmental Management in Australia, 1788-1914, Melbourne, p. 18.
} 
The histories exposed in the language of water and rivers leads directly us to question the meanings held of it. While these meanings diverge between waters considered to be 'fresh' and those which are 'salt', the complexity of meanings is common to them both. The shared human need for water as an essential biological demand has generated a rich and multilayered engagement with water in individual psychological and in social terms. This is inflected by cultural processes, so that the ways in which different national or religious cultures understand water may not only be varied but can be in intense conflict, changing over time but also in the course of such conflicts. So migrancy, the flow of new people into a relationship with water, will bring new ideas, new interactions and potentially, new conflicts.

The first five of the papers in this volume engage directly with this question of meanings, but do so in very different ways. Jeff Malpas addresses the philosophical and experiential dimensions of water, exploring how the fluidity of water both materially and conceptually has played a key role in allowing people to nurture their understandings of places. Malpas argues for the ambiguity of water in its many forms, as offering both borders and highways, and in doing so constituting the places around it. Veronica Strang traces the course of the Brisbane River from rural 'resource' to urban scene, suggesting the ways the complex material transformations which its waters generate in their course through rural industries are paralleled in the conflict-ridden debates about what constitutes 'rurality' and 'the city'. Trish FitzSimons explores at an even more personal level the shifts in meaning over time of a fresh water spring, at Peat's Ridge. The diverse histories of marginal migrant farmers on the infertile sandstone escarpments on the urban edge of Sydney were transformed by the commodification of spring water into a desired urban product, and then where transformed again by the incorporation of their family businesses into the transnational giants of the bottled water industry. The changing intersections of personal meanings and economic forces traced by both Strang and FitzSimons demand reflective consideration along the lines Malpas suggests to appreciate the ways in which water and place are mutually constitutive.

Where Malpas, Strang and FitzSimons explore fresh water questions, Paul D’Arcy and Dirk Spennemann explore the meanings of water for Pacific peoples, whom the west 
associates with tiny islands, but for whom D'Arcy describes a broad expanse of dwelling across seas which act as highways not barriers. He argues that until recently the oceans were seen by Islanders to be inviting corridors and connectors. It has been the skills of seafaring across their expansive oceans rather than the exposed earth of the islands which in the past has defined island societies in the Pacific. This expansive concept of Pacific societies has now been miserably shrunken down. International recognition of legal boundaries has effectively limited the definition of 'nations' to land masses alone, while at the same time the knowledge and confidence about over the horizon navigation and the other skills which seafaring islanders once had is being eroded by the shifting demands of Pacific modernities. For Spennemann, however, the core of each Pacific island is the lens of freshwater which saturates the central heart of the island, allowing plants, animals and humans to survive in what would otherwise be a fatally saline environment. Spennemann's paper demonstrates that again, issues of political sovereignty and international law are in conflict with local knowledge and in this case with the science of water and geology, in a tense engagement which means literally life and death for people and Pacific nations.

For each of the authors contributing to this volume, the questions about the meaning of water are not only philosophical and imaginative, but are intensely political. They have consequences in the everyday world, in which real people bear the costs of the power struggles occurring over the politics of mobilising the meanings of rivers. The next group of papers addresses the questions around whether water is regarded as a commons and by whom. Janice Gray traces the way the legal structures in Australia, and particularly in New South Wales, were generated from a piecemeal inheritance from the United Kingdom, interacting with the intractable physical environment in Australia with its limited and variable surface waters and interacting again with the intensifying penetration of a globalising market. The outcome has been a shift from public ownership of the rights to access water to an intensifying commodification of water and a privatisation of the rights to its access. Tony McAvoy, Indigenous lawyer and environmental advocate, takes up the implications of these changing land and water laws for the complex societies of Aboriginal people, like the Cadigal and the Wangal Wangal peoples of Sydney and many others across the continent, for whom water holds a very different set of meanings. McAvoy considers the problems arising from the sudden creation of a property market in water after the recognition of rights in land 
arising from the 1983 NSW Land Rights Act and then the Native Title judgement of the Australian High Court in 1992. He asks whether there can be legal or political strategies which allow recognition and respect for the cultural meanings of water which continue to be of central importance to Aboriginal people in contemporary Australia. Phil Hirsch considers management of water as an international commons in a transboundary river in the long Mekong River complex in South East Asia. Local people along the length of the river have long-established approaches to managing water as a commons but these are impacted on by bureaucratisation, infrastructure and commodification. Hirsch argues that the transboundary basin organisations can both enhance and undermine governance for the common good, depending on how they deal with commonality of interest in freshwater at various scales, but that the appearance of overall success in basin-level management can hide some troubling ways in which water as a commons is eroded in the process of development.

Finally, the question of the relation between water and borders, whether international or regional, is tackled directly by Webber within China in relation to the Yellow River and the Yangze; by Kanasa in colonial New Guinea and by Hill in relation to the massive, trans-border river systems in South Asia. Webber et al undertake a careful analysis of the political impact of the proposed governance and engineering decisions involved in the management of water in the Yellow River valley, where the implications of transfers of water from one region to another will have major effects on the people of both river valleys. Biama Kanasa introduces new historical work in the interaction of inter-empire conflict between British and German colonial administrations on the border of Papua and New Guinea where the people who are left to make sense of the unworkable international boundary are the local and unconsulted village owners. Douglas Hill examines the recent changes in the complex management of the Indus River in the west, shared since Partition in 1947 between India and Pakistan and the Ganges-BrahmaputraMeghna basin in the east, where the governments of India, Nepal and Bangladesh are all involved in decision-making. These rivers continue to flow through largely agricultural economies, and the contesting interests at work in pressuring governments over river control are different from those operating in economies like China and Australia where industrial uses and energy production currently make ever higher demands on river systems. Nevertheless, the rising pressures of highly capitalised development strategies, like intensifying agriculture, as well as the political impact of displacements of 
populations, have generated recent shifts in cross border decision making on rivers which, particularly in the east with the Farakka Barrage, have generated new tensions. Just as significantly, Hill points out that the management of surface waters is open to negotiation through the multilayered processes of formal agreements. However, with the increasingly evident limitations of those waters under the pressures of developmental strategies, there has been a major increase in the exploitation of ground water, which is far less accessible either to the quantification of its depletion or to negotiated agreements over sustainable and equitable rates of extraction. So the use of water has escaped the legal and political boundaries established over either fresh river water or salt sea water, detaching it from political borders and giving a sense of it being once again 'a commons' but in fact looking easily close to the uncontrolled mining of a limited source.

While directing their primary focus to the themes of freshwater or salt, commons or borders, all these papers have engaged deeply with the problems of the complex and shifting meanings of water and the intensely politicised context in which the conflicts over its meanings are played out. They each demonstrate that water debates, whether conducted in the spheres of politics or economics and in the language of science, social science or the humanities, have real consequences for real people. The hand stencils of the Cadigal and the Wangal Wangal people on the sandstone cliffs around Sydney Harbour and its rivers do more than foreground the complex cultures of Aboriginal Australia, they demand we consider the very human qualities of our interaction with water at the same time as we seek to grasp its ecological as well as its political dimensions.

\section{References}

Boulton, A.J., \& P.J. Hancock (2006) "Rivers as groundwater-dependent ecosystems: a review of degrees of dependency, riverine processes and management implications." Australian Journal of Botany 54: 133-44.

Powell, J.M. (1976) Environmental Management in Australia, 1788-1914. Melbourne: Oxford University Press.

- (1991) Plains of Promise, Rivers of Destiny: Water Management and the Development of Queensland, 1824-1990. Bowen Hills, Qld: Boolarong Publications.

Ransom, W.S. (ed) (1988) The Australian National Dictionary. Melbourne: Oxford University Press. 